\title{
An Innovative Approach to the Forecasting of Energetic Effects While Wood Sawing
}

\section{Inovativni pristup predviđanju energijskih veličina tijekom piljenja drva}

\author{
Original scientific paper • Izvorni znanstveni rad \\ Received-prispjelo: 15. 7. 2013. \\ Accepted-prihvaćeno: 13. 10. 2014. \\ UDK: $630 * 822.02$ \\ doi:10.5552/drind.2014.1341
}

\begin{abstract}
In the classical approach, energetic effects (cutting forces and cutting power) of wood sawing process are generally calculated on the basis of the specific cutting resistance, which is in the case of wood cutting the function of more or less important factors. On the other hand, the cutting forces (power) problem may be tackled with an innovative, up-to-date fundamental analysis of the mechanics of sawing based on modern fracture mechanics. This line of attack is an improvement on traditional approaches for cutting forces and power, many of which are empirical and based upon limited information. Such formulae do not permit generalisation to new conditions of operation of sawmills, such as e.g. the use of narrow-kerf blades. The presented algebraic model, for cutting power determination while sawing, in addition to timber 'strength' and friction between tool and workpiece, takes into account the property called 'fracture toughness' (resistance to cracking), which is a vital ingredient. Furthermore, forecasting of the shear plane angle with this model is achievable even for small values of uncut chips. Moreover, the mentioned model is a universal one, and useful for determination of energetic effects of sawing of every kinematics such as: frame sawing machines, bandsawing machines and circular sawing machines.
\end{abstract}

Key words: energetic effects, cutting power, wood sawing process, sawing machines, fracture mechanics, fracture toughness

SAŽETAK • U klasičnom pristupu energijske se veličine (sile rezanja i snaga rezanja) tijekom procesa piljenja drva obično izračunavaju na temelju specifičnog otpora rezanja, koji je pri rezanju drva funkcija više ili manje važnih čimbenika. Nasuprot tomu, problem određivanja sila rezanja i snage rezanja može se riješiti inovativnim pristupom uz primjenu temeljne analize mehanike piljenja koja se temelji na modernoj mehanici loma. Taj način pristupa određivanju sila rezanja i snage rezanja poboljšanje je s obzirom na tradicionalne metode, od kojih su mnoge empirijske i utemeljene na ograničenim podacima. Takve empirijske formule ne dopuštaju poopćenje prema novim uvjetima rada pilane, kao što je primjena tankih pila s malom širinom propiljka. Predstavljeni algebarski model za određivanje snage rezanja tijekom piljenja osim čvrstoće drva i trenja između alata i obratka uzima u obzir i svojstvo pod nazivom lomna žilavost (otpornost na pucanje), koje je ključni utjecajni čimbenik na snagu

\footnotetext{
${ }^{1}$ Author is a professor at the Gdansk University of Technology, Faculty of Mechanical Engineering, Department of Manufacturing Engineering and Automation, Gdansk, Poland. ${ }^{2}$ Author is a researcher at The Szewalski Institute of Fluid-Flow Machinery, Polish Academy of Sciences, Department of Transonic Flows and Numerical Methods, Gdansk, Poland. ${ }^{3}$ Author is an emeritus professor at the University of Reading, School of Construction Management and Engineering, Whiteknights, Reading, Berkshire, United Kingdom.

Autor je profesor Fakulteta strojarstva Tehnološkog sveučilišta u Gdanjsku, Gdanjsk, Poljska. ${ }^{2}$ Autor je znanstvenik Poljske akademije znanosti, Gdanjsk, Poljska. ${ }^{3}$ Autor je profesor emeritus Sveučilišta u Readingu, Reading, Berkshire, Ujedinjeno Kraljevstvo.
} 
rezanja. Nadalje, predviđanje kuta smicanja ravnine opisanim modelom ostvarivo je čak i za male vrijednosti debljine strugotine. Osim toga, model je univerzalan i primijenjiv za određivanje energijskih veličina pri različitim kinematikama rezanja kao što su piljenje pilom jarmačom, tračnom pilom i kružnom pilom.

Ključne riječi: energijske veličine, snaga rezanja, proces piljenja drva, strojevi za piljenje, mehanika loma, lomna žilavost

\section{INTRODUCTION}

\section{UVOD}

The mechanics of cutting wood has traditionally been interpreted in terms of the Ernst-Merchant model for cutting ductile metals in which, for given blade geometry and uncut chip thickness, the important parameters are mainly the strength of the material and friction between blade and workpiece (Manžos, 1974; Orlicz, 1988; Orlowski, 2007; Scholz et al., 2009; Naylor et al. 2011). Recent work in the mechanics of cutting (Atkins, 2009) shows that the resistance to cracking of the workpiece (the so-called fracture toughness) is just as significant as strength and friction in determining the forces and power to cut. Furthermore, incorporation of toughness in the new analysis predicts quantitatively many features that the Ernst-Merchant analysis fails to, such as values of the primary shear plane angle, the anomalous rise in specific cutting resistance at small uncut thicknesses, the transition to different types of chip, and so on. The new theory also gives physical meaning to terms in many empirical expressions for the forces and power to cut timber.

The present paper applies the new theory to the cutting of pine (Pinus sylvestris L.) by three different sorts of sawing machines, namely a sash gang saw, a circular saw and a bandsaw. Measured forces and power, as they change under different cutting conditions, are predicted by the theory. The capacity of the three sawing machines is discussed in terms of available power, feed rates and so on, leading to comments on the design of machines with different kinematic features.

\section{THEORETICAL BACKGROUND 2. TEORIJSKA OSNOVA}

Orlowski et al. (2013) have proved that cutting power models, which are based on modern fracture mechanics, are useful for estimation of energetic effects of sawing of every kinematics. According to Atkins (2009) and Orlowski (2010), moreover, taking into account that the chips have to be accelerated to the same velocity as the cutting tool velocity $v_{\mathrm{c}}$ (Atkins, 2009; Pantea, 1999), cutting power for one saw blade during the cutting stroke on a sash gang saw (for a whole cycle it means working and idling strokes $P_{\mathrm{c}}=0.5 \cdot \bar{P}_{\mathrm{cw}}$ (Orlowski, 2010; Orlowski and Palubicki, 2009), and during cutting on a bandsaw machine, as their sawing kinematics are similar (Fig. 1a), has the following mathematical formula:

$$
\begin{aligned}
\bar{P}_{\mathrm{cw}}=F_{\mathrm{c}} \cdot v_{\mathrm{c}}+P_{\mathrm{ac}}= & {\left[z_{\mathrm{a}} \cdot \frac{\tau_{\gamma} \cdot S_{\mathrm{t}} \cdot \gamma}{Q_{\text {shear }}} \cdot v_{\mathrm{c}} \cdot f_{\mathrm{z}}+\right.} \\
& \left.+z_{\mathrm{a}} \cdot \frac{R_{\perp} \cdot S_{\mathrm{t}}}{Q_{\text {shear }}} \cdot v_{\mathrm{c}}\right]+P_{\mathrm{ac}}
\end{aligned}
$$

where: $z_{\mathrm{a}}=\left(\frac{H_{\mathrm{P}}}{P}\right)$ is an average number of teeth being in contact with the kerf, $P$ is tooth pitch, $H_{\mathrm{p}}$ is workpiece height (cutting depth), $\tau_{\gamma}$ is the shear yield stress, $\gamma$ is the shear strain along the shear plane, which is given by:

$$
\gamma=\frac{\cos \gamma_{\mathrm{f}}}{\cos \left(\Phi_{c}-\gamma_{\mathrm{f}}\right) \cdot \sin \Phi_{\mathrm{c}}}
$$

$f_{\mathrm{z}}$ is feed per tooth, $h$ uncut chip thickness, $S_{\mathrm{t}}$ is a kerf width (the width of orthogonal cut), $\beta_{\mu}$ is friction angle which is given by $\tan ^{-1} \mu=\beta_{\mu}$, with $\mu$ the coefficient of friction, $\gamma_{f}$ is the rake angle, $\Phi_{c}$ is the shear angle which defines the orientation of the shear plane with respect to cut surface, $R_{\perp}$ is specific work of surface separation/formation (fracture toughness), and $Q_{\text {shear }}$ is the friction correction:

$Q_{\text {shear }}=\left[1-\left(\sin \beta_{\mu} \cdot \sin \Phi_{\mathrm{c}} / \cos \left(\beta_{\mu}-\gamma_{f}\right) \cdot \cos \left(\Phi_{\mathrm{c}}-\gamma_{f}\right)\right)\right]$

For least force $F_{\mathrm{c}}$ the shear angle $\Phi_{\mathrm{c}}$ satisfies (Atkins 2003):

$\left[1-\frac{\sin \beta_{\mu} \cdot \sin \Phi_{\mathrm{c}}}{\cos \left(\beta_{\mu}-\gamma_{\mathrm{f}}\right) \cdot \cos \left(\Phi_{\mathrm{c}}-\gamma_{\mathrm{f}}\right)}\right] \cdot\left[\frac{1}{\cos ^{2}\left(\Phi_{\mathrm{c}}-\gamma_{\mathrm{f}}\right)}-\frac{1}{\sin ^{2} \Phi_{\mathrm{c}}}\right]=$
$=-\left[\cot \Phi_{\mathrm{c}}+\tan \left(\Phi_{\mathrm{c}}-\gamma_{f}\right)+Z\right] \cdot\left[\frac{\sin \beta_{\mu}}{\cos \left(\beta_{\mu}-\gamma_{\mathrm{f}}\right)}\left\{\frac{\cos \Phi_{\mathrm{c}}}{\cos \left(\Phi_{\mathrm{c}}-\gamma_{\mathrm{f}}\right)}+\right.\right.$
$\left.\left.+\frac{\sin \Phi_{\mathrm{c}} \cdot \sin \left(\Phi_{\mathrm{c}}-\gamma_{\mathrm{f}}\right)}{\cos ^{2}\left(\Phi_{\mathrm{c}}-\gamma_{\mathrm{f}}\right)}\right\}\right]$

in which $Z=\frac{R}{\tau_{\gamma} \cdot f_{z}}$ is the parameter which makes $\Phi_{\text {c }}$ material dependent. Equation (4) is solved numerically.

Since, wood is an anisotropic material, its physical and mechanical properties differ in the three principal directions relative to the trunk of the tree (Fig. 2): longitudinal (L, axial), which is parallel to tree trunk and parallel to long axis of longitudinally oriented cells (tracheids and fiber tracheids); radial (R), which is perpendicular to longitudinal direction and parallel to the radius of the trunk and wood rays; and tangential (T), which is perpendicular to longitudinal direction and parallel to growth rings (FPL 1980). For that reason, values of $R$ and $\tau_{\gamma}$ should be applied accordingly to the cutting speed direction in regard to the wood grain direction (Jeronimidis, 1980; Kretschmann, 2010), which is mainly a function of the sawing kinematics.

The chip acceleration power $P_{a c}$ variation as a function of mass flow and tool velocity is given by:

$$
P_{\mathrm{ac}}=\dot{m} \cdot v_{\mathrm{c}}^{2}
$$

where: $\dot{m}\left(\mathrm{~kg} \cdot \mathrm{s}^{-1}\right)$ represents the mass of wood (chips) evacuated in a certain period of time at the certain cut- 
a)

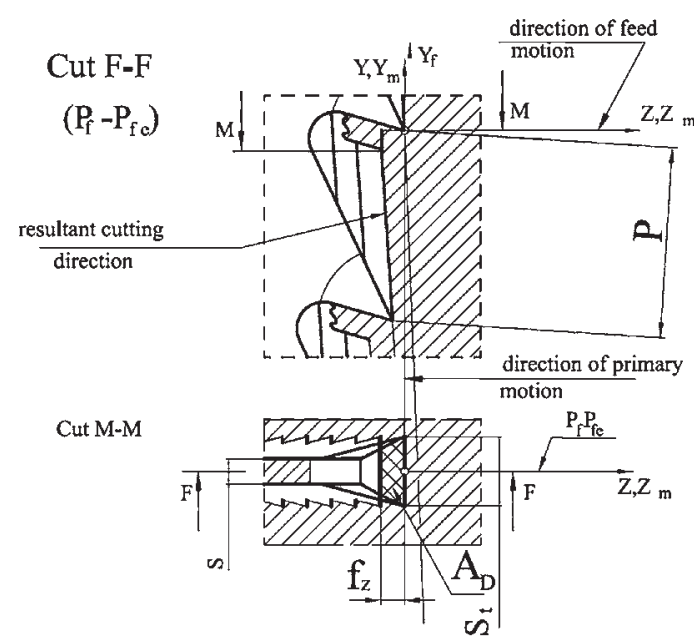

b)

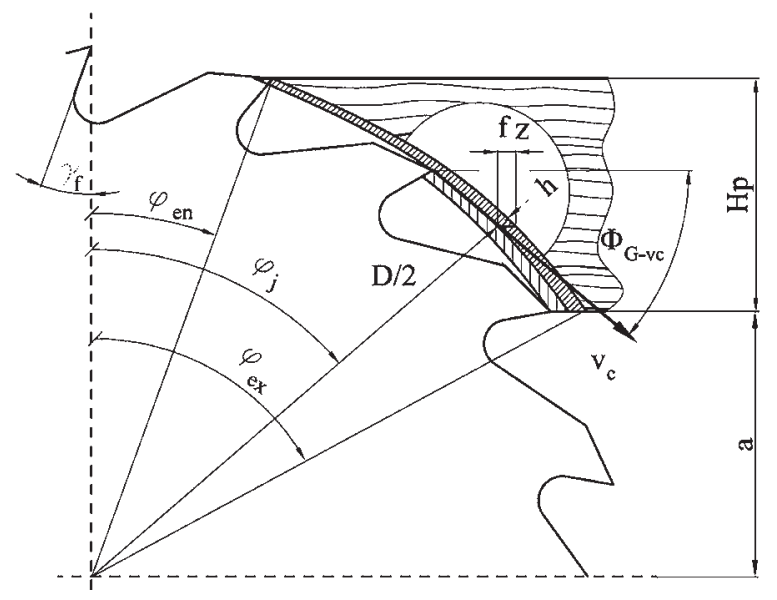

Figure 1 Sawing kinematics (a) on the sash gang saw and band sawing machine, along with kinematics on (b) circular sawing machine, where: $f_{\mathrm{z}}$ - feed per tooth, $s$ - saw blade thickness, $A_{\mathrm{D}}$ - area of the cut, $P$ - pitch, $Y, Z$ and $Y_{\mathrm{M}}, Z_{\mathrm{M}}$ - machine coordinate and setting axes, $Y_{\mathrm{f}}-f$-set coordinate axis, $P_{\mathrm{fe}}$ - working plane, $D$ - circular saw blade diameter, $h$ - uncut chip thickness, $H_{\mathrm{p}}$ - workpiece height (depth of cut), $a$ - position of the workpiece, $\varphi$ - angular tooth position, $\Phi_{\mathrm{G}-\mathrm{vc}}-$ an angle between grains and the cutting speed direction (Orlowski et al., 2013)

Slika 1. Kinematika piljenja (a) na pili jarmači i tračnoj pili, (b) na kružnoj pili, gdje je: $f_{\mathrm{z}}$ - posmak po zubu, $s$ - debljina lista pile, $A_{\mathrm{D}}$ - površina rezanja, $P$ - korak zuba, $Y, Z$ i $Y_{\mathrm{M}}, Z_{\mathrm{M}}$ - koordinate stroja i postavljene osi, $Y_{\mathrm{f}}-f$-set koordinatne osi, $P_{\mathrm{fe}}-$ radna ravnina, $D$ - promjer kružne pile, $h$ - debljina strugotine, $H_{\mathrm{p}}$ - visina obratka (debljina rezanja), $a$ - pozicija obratka, $\varphi$ - kutna pozicija zuba, $\Phi_{\mathrm{G}-\mathrm{vc}}-$ kut između vlakanaca i smjera brzine rezanja (Orlowski et al., 2013.)

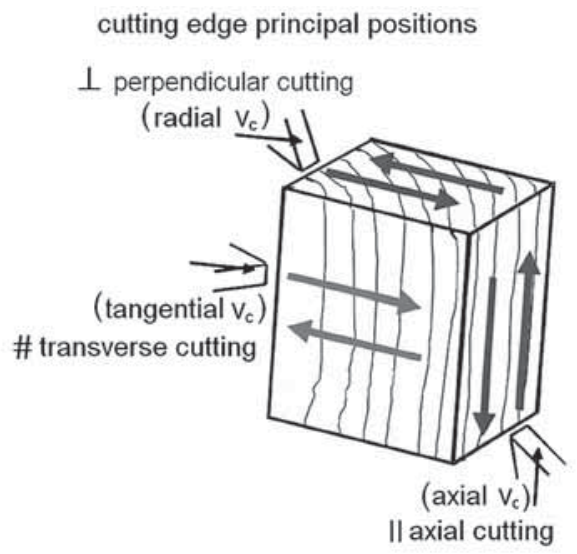

Figure 2 Tooth cutting edge principal positions and cutting speed directions (adapted by authors from Laternser et al., 2003; Orlowski et al., 2013)

Slika 2. Osnovne pozicije rezne oštrice i smjerovi brzine rezanja (prilagođeno prema Laternser et al., 2003.; Orlowski et al., 2013.)

ting tool velocity $v_{\mathrm{c}}$ (cutting speed), which can be calculated as follows:

$$
\dot{m}=H_{\mathrm{P}} \cdot S_{\mathrm{t}} \cdot v_{\mathrm{f}} \cdot \rho
$$

where: $v_{\mathrm{f}}$ is feed speed and $\rho$ is the density of sawn wood. It should be emphasized, that in these analyses, it was assumed that the power $P_{a c}$ is not a function of the number of working teeth. In case of both the circular sawing machine and the bandsawing machine, the chip acceleration power $P_{a c}$ is several hundred times larger in comparison with the sash gang saw (Orlowski et al., 2013), thus, for the latter machine tool, the last term of Eq.(1) can be omitted.

Kinematics of sawing on circular sawing machines (Fig. 1b) differs from kinematics of cutting on sash gang saws and bandsawing machines (Fig. 1a). In case of cutting with circular saw blades, uncut chip thickness $\bar{h}$ (an average value e.g.) instead of feed per tooth $f_{\mathrm{z}}$ should be taken into account, hence, the cutting power may be expressed as:

$\bar{P}_{\mathrm{cw}}=F_{\mathrm{c}} \cdot v_{\mathrm{c}}+P_{a c}=\left[z_{\mathrm{a}} \cdot \frac{\tau_{\gamma} \cdot S_{\mathrm{t}} \cdot \gamma}{Q_{\text {shear }}} \cdot v_{\mathrm{c}} \cdot \bar{h}+z_{\mathrm{a}} \cdot \frac{R \cdot S_{\mathrm{t}}}{Q_{\text {shear }}} \cdot v_{\mathrm{c}}\right]+P_{a c}$

where: $z_{\mathrm{a}}=\left(\frac{\varphi_{2}-\varphi_{1}}{\varphi_{\mathrm{t}}}\right)$ is a number of teeth being in contact with the kerf (average), $\varphi_{1}$ is an angle of teeth entrance which is given by $\varphi_{1}=\arccos \frac{2 \cdot\left(H_{\mathrm{p}}+a\right)}{D_{\mathrm{cs}}}, \varphi_{2}$ is an exit angle which can be determined as $\varphi_{2}=\arccos \frac{2 \cdot a}{D_{\mathrm{cs}}}$, $D_{\text {cs }}$ is a diameter of circular saw blade, an average uncut chip thickness is given by $\bar{h}=f_{\mathrm{z}} \cdot \sin \bar{\varphi}$, and an average angle of tooth contact with a workpiece $\bar{\varphi}$ is calculated from $\bar{\varphi}=\frac{\varphi_{1}+\varphi_{2}}{2}$.

Furthermore, it is difficult to presume that in this kind of sawing kinematics there is a case of perpendicular cutting, because the angle between the grains and the cutting speed direction differs from $90^{\circ}$, as it was assumed for the sash gang saw and the band sawing machines. Hence, taking into account the position of the cutting edge in relation to the grains, for indirect positions of the cutting edge fracture, toughness $R$ and the shear yield stress $\tau_{\gamma}$ may be calculated from formulae known from the strength of materials (Orlicz, 1988). For example for cutting on circular sawing machines (a case of axial-perpendicular cutting), these material features are as follows:

$$
R_{\| \perp}=R_{\|} \cdot \cos ^{2} \Phi_{\mathrm{G}-\mathrm{vc}}+R_{\perp} \cdot \sin ^{2} \Phi_{\mathrm{G}-\mathrm{vc}}
$$


Table 1 Tool and machine tool data

Tablica 1. Podaci o alatu i stroju

\begin{tabular}{|c|c|c|c|c|}
\hline \multirow[t]{2}{*}{$\begin{array}{l}\text { Parameter } \\
\text { Parametar }\end{array}$} & \multirow[t]{2}{*}{$\begin{array}{c}\text { Sash gang saw DTRB-63 } \\
\text { (f. FOD) } \\
\text { Pila jarmača DTRB-63 }\end{array}$} & \multicolumn{2}{|c|}{$\begin{array}{c}\text { Double shaft multi ripsaw } \\
\text { PRW } 422 \text { (f. TOS Svitavy) } \\
\text { Dvovretena višelisna kružna pila } \\
\text { PRW } 422\end{array}$} & \multirow[t]{2}{*}{$\begin{array}{l}\text { Bandsawing machine } \\
\text { ST-100R (f. Stenner) } \\
\text { Tračna pila ST-100R }\end{array}$} \\
\hline & & Upper / Gornja & Lower / Donja & \\
\hline$H_{\mathrm{p}}, \mathrm{mm}$ & 235.4 & 54.8 & 82.2 & 95 \\
\hline$n_{\mathrm{sb}}, \mathrm{mm}$ & 6 & 9 & 9 & 1 \\
\hline$S_{\mathrm{t}}, \mathrm{mm}$ & 3.9 & \multicolumn{2}{|c|}{3.9} & 2.2 \\
\hline$P, \mathrm{~mm}$ & 25 & \multicolumn{2}{|c|}{-} & 40 \\
\hline$\gamma_{\mathrm{f}},{ }^{\mathrm{o}}$ & 18 & \multicolumn{2}{|c|}{22} & 25 \\
\hline $\mathrm{z}$ & 38 & \multicolumn{2}{|c|}{18} & 138 \\
\hline$v_{\mathrm{c}}, \mathrm{m} / \mathrm{s}$ & 5.2 & \multicolumn{2}{|c|}{69.6} & 35 \\
\hline$v_{\mathrm{f}}, \mathrm{m} / \mathrm{min}(\mathrm{m} / \mathrm{s})$ & $1.2-9(0.02-0.15)$ & \multicolumn{2}{|c|}{$4-40(0.07-0.67)$} & $5-60(0.083-1)$ \\
\hline$f_{\mathrm{z}}, \mathrm{mm}^{*}$ & $0.19-1.44$ & \multicolumn{2}{|c|}{$0.058-0.56$} & $0.095-1.14$ \\
\hline$h, \mathrm{~mm}^{*}$ & $0.19-1.44$ & $0.033-0.32$ & $0.028-0.27$ & $0.095-1.14$ \\
\hline$v_{\mathrm{f}}, \mathrm{m} / \mathrm{min}(\mathrm{m} / \mathrm{s})$ applied & $3.9(0.065)$ & \multicolumn{2}{|c|}{$16(0.27)$} & $45(0.75)$ \\
\hline$f_{\mathrm{z}}, \mathrm{mm}$, applied & 0.625 & \multicolumn{2}{|c|}{0.233} & 0.86 \\
\hline$h, \mathrm{~mm}$, applied & 0.625 & 0.131 & 0.111 & 0.86 \\
\hline$P_{\mathrm{EM}}, \mathrm{kW}$ & 45 & 110 & 110 & 15 \\
\hline$P_{\mathrm{i}}, \mathrm{kW}$ & 19 & 14 & 14 & 2.5 \\
\hline$P_{\mathrm{cA}}, \mathrm{kW}\left(P_{\mathrm{cA}}^{1}\right)$ & $20.8(3.46)$ & $76.8(8.53)$ & $76.8(8.53)$ & $10(10)$ \\
\hline
\end{tabular}

Legend: *The values used in computation of predicted cutting powers, $P_{\mathrm{FM}}-$ electric motor power, $P_{\mathrm{i}}-$ idling power, $P_{\mathrm{cA}},\left(P_{\mathrm{cA}}^{1}\right)-$ available cutting power in the cutting zone (available cutting power per one saw blade), $n$ - number of saw blades

Legenda: * vrijednosti korištene u računanju predviđene snage rezanja, $P_{\mathrm{EM}}-$ snaga elektromotora, $P_{\mathrm{i}}-$ snaga u praznom hodu, $P_{\mathrm{cA}},\left(P_{\mathrm{cA}}^{1}\right)-$ raspoloživa snaga u zoni rezanja (raspoloživa snaga rezanja za jednu pilu), $n_{\mathrm{sb}}$ - broj pila

and

$$
\tau_{\gamma \| \perp}=\tau_{\gamma \|} \cdot \cos ^{2} \Phi_{\mathrm{G}-\mathrm{vc}}+\tau_{\gamma \perp} \cdot \sin ^{2} \Phi_{\mathrm{G}-\mathrm{vc}}
$$

where: $\Phi_{\mathrm{G}-\mathrm{rc}}$ is an angle between grains and the cutting speed direction (Fig. 1b).

\section{MATERIAL AND METHODS} 3. MATERIJAL I METODE

Predictions of cutting power have been made for the case of bona fide sawing processes on the sash gang saw DTRB-63 (f. FOD, PL, Fig. 3a), the double shaft multi ripsaw PWR422 (f. TOS Svitavy, CZ, Fig. 4) and the bandsawing machine ST100R (f. Stenner, UK, Fig.
5), which are installed in a Polish sawmill in the Cassubia Region in Poland. The basic sawing machines data and cutting parameters for which computations were done are shown in Table 1.

The raw material was pine wood (Pinus sylvestris $\mathrm{L}$.) with the depth of cut equal to $H_{p}$. The raw material derived from the Baltic Natural Forest Region (A, Fig. 6), the Carpathian Natural Forest Region (B), the Little Poland Natural Forest Region (C) and the Great Poland-Pomeranian Natural Forest Region (D) in Poland. Moisture content was MC 8.5-12 \% for bandsawing, and $\mathrm{MC} \sim 30 \%$ for both the sash gang saw and the rip saw. For that reason, the latter cutting power results were additionally multiplied by 1.05 (Manžos, a)

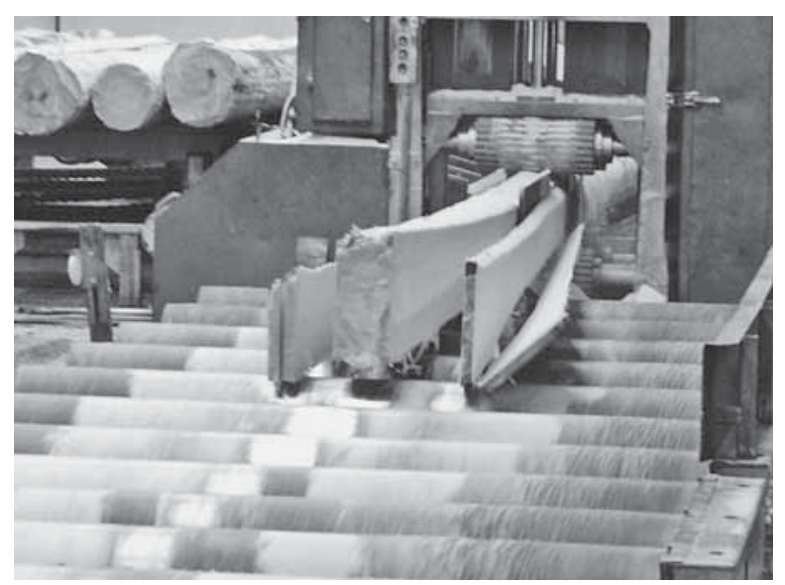

b)

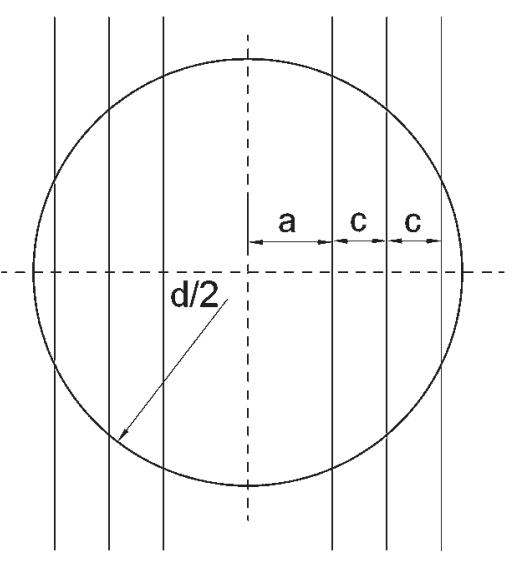

Figure 3 Sash gang saw DTRB-63 (a) and applied sawing pattern (b) Slika 3. Pila jarmača DTRB-63 (a) i primijenjeni raspored pila (b) 
a)

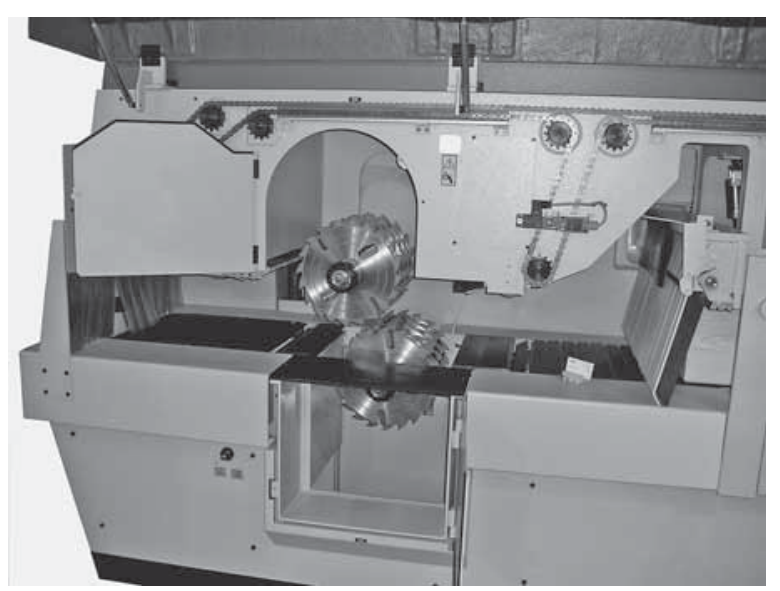

b)

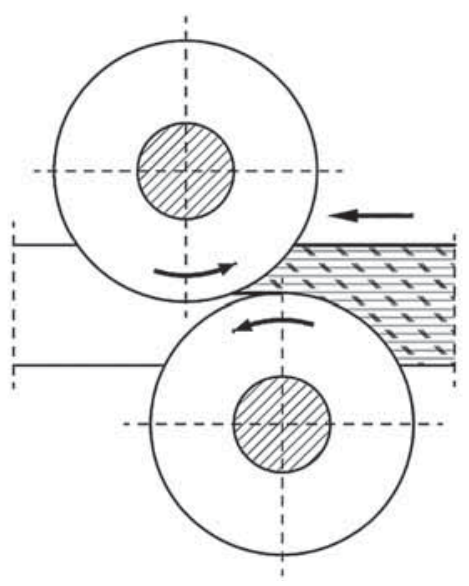

Figure 4 Double shaft multi ripsaw PWR422 (a, Web_source 1, 2013), along with kinematics and division of depth of cut (b)

Slika 4. Dvovretena višelisna kružna pila PWR422 (a), kinematika i podjela debljine rezanja (b)

1974). The value of kinetic friction coefficient $\mu=0.6$ for dry pine wood was taken according to Glass and Zelinka (2010), and Beer (2002).

In the case of circular sawing in which indirect positions of the cutting edge are present, $R$ and $\tau_{\gamma}$ have to be calculated from formulae (8) and (9) (Orlowski et al., 2013). According to Aydin et al. (2007), it was assumed that fracture toughness of pine for longitudinal (axial) cutting $R_{\|}=0.05 R_{\perp}$. Moreover, an assumption was made that in case of pine wood, for axial cutting, the shear yield stress $\tau_{\gamma \|}$ is equal to $0.125 \times \mathrm{MOR}$ (modulus of rupture in bending (Kretschmann, 2010; Krzysik, 1974)). The set of the raw material is presented in Tab. 2. Values of $R_{\perp}$ and $\tau_{\gamma \perp}$ were determined during sawing tests according to the methodology described in works by Orlowski and Atkins (2007) and Orlowski and Palubicki (2009). It should be emphasised that in the latter tests, the same samples were applied as in the experiments carried out by Krzosek (2009).

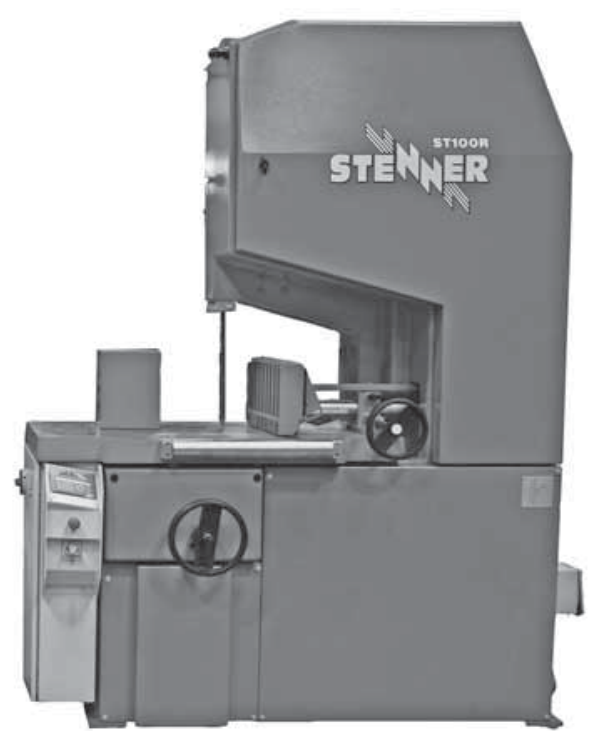

Figure 5 Bandsawing machine ST100R (Stenner, 2012) Slika 5. Tračna pila ST100R (Stenner, 2012.)

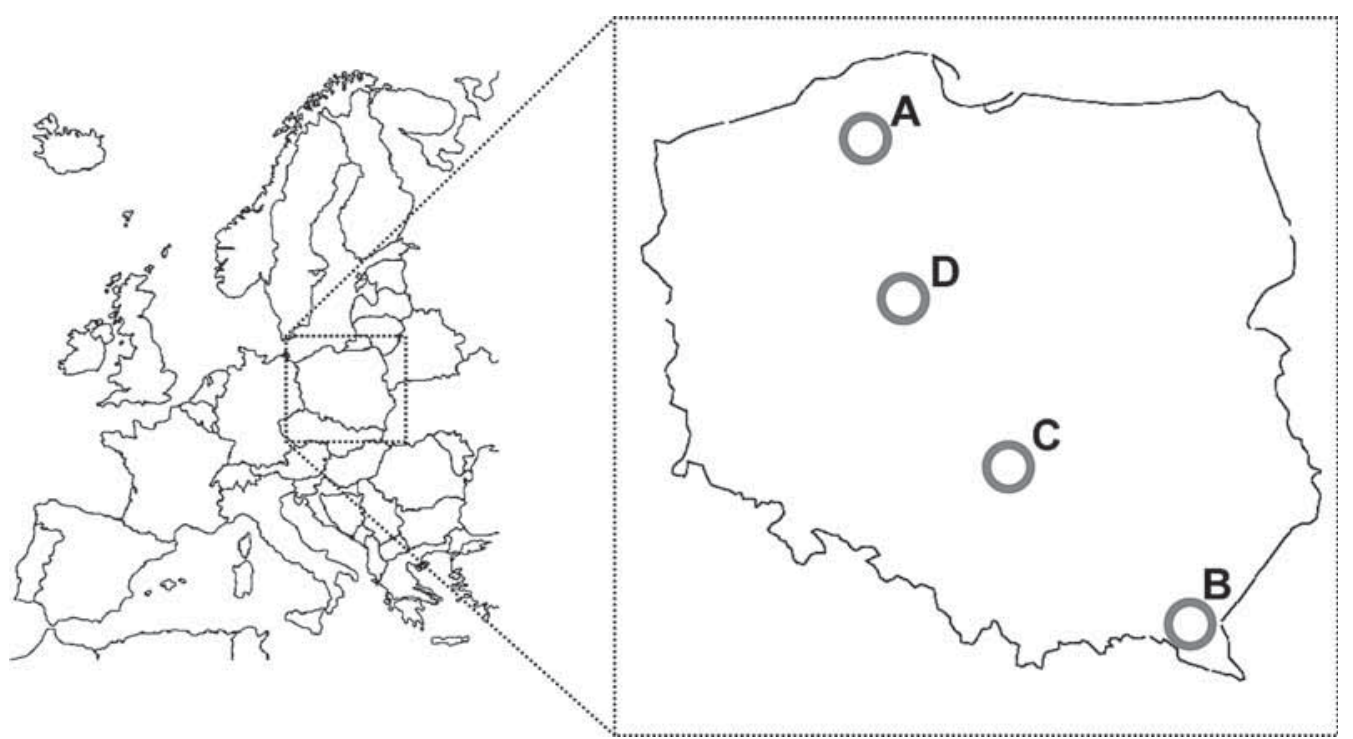

Figure 6 Locations of Polish Natural-Forest Regions of pine wood provenance Slika 6. Lokacije prirodnih šuma bora u Poljskoj 
Table 2 Raw material data (Orlowski et al., 2012)

Tablica 2. Podaci o materijalu (Orlowski et al., 2012.)

\begin{tabular}{|c|c|c|c|c|}
\hline \multirow{2}{*}{$\begin{array}{l}\text { Region } \\
\text { Regija }\end{array}$} & $\rho$ & $\boldsymbol{R}_{\perp}$ & $\tau_{\gamma \perp}$ & MOR* \\
\hline & $\mathrm{kg} \cdot \mathrm{m}^{-3}$ & $\mathrm{~J} \cdot \mathrm{m}^{-2}$ & $\mathrm{kPa}$ & $\mathrm{MPa}$ \\
\hline $\mathrm{A}$ & 520 & 1295.33 & 20861 & 41,6 \\
\hline B & 439 & 1496.32 & 16846 & 25,3 \\
\hline $\mathrm{C}$ & 478 & 1267.17 & 17986 & 35,2 \\
\hline $\mathrm{D}$ & 589 & 1141.29 & 29521 & 45,1 \\
\hline
\end{tabular}

$\rho$ - density, MOR - modulus of rupture in bending (* values were taken from Krzosek 2009)

$\rho$ - gustoća, MOR - modul loma pri savijanju (*vrijednosti preuzete od Krzosek, 2009.)

The sawing pattern for the sash gang saw, in which thickness of the main material is $2 a=137 \mathrm{~mm}$, with 2 boards of $27.5 \mathrm{~mm}$ in thickness additionally obtained on each side, is presented in Fig. 3b. Logs with diameter $d_{g}$ in thinner end (top diameter) about 11" (imperial units are still in use in sawmill practice, $d_{g}$ $\approx 290 \mathrm{~mm}$ ), and $l=4 \mathrm{~m}$ in length are sawn. The workpiece thickness $H_{P}$ presented in Tab. 1 is in this case an average value of the kerf depth determined in the middle of the log length. In order to estimate a middle log diameter $d$, the taper coefficient $T C(\mathrm{~cm} / \mathrm{m}$, the degree of taper) was calculated as follows (Leśnik, 2013):

$T C=\frac{1}{10} \cdot\left[6.2+74 \cdot l^{-3}+\left(\frac{0.48}{\sqrt{l}}-0.12\right) \cdot\left(d_{\mathrm{g}}-22+0.3 \cdot l\right)\right](10)$

where: $l$ is the log length in $\mathrm{m}$, and $d_{\mathrm{g}}$ is the top diameter without bark in $\mathrm{cm}$. Thus, in this case $T C=0.834 \mathrm{~cm} / \mathrm{m}$, and for this data middle log diameter is $d=30.66 \mathrm{~cm}$. The latter value was applied in calculations of the total kerf height $H_{\Sigma}$ as follows (Csanády and Magoss, 2013):

$$
H_{\Sigma}=4 \sum_{i=1}^{i=k} \sqrt{\left(\frac{d}{2}\right)^{2}-[a+(i-1) \cdot c]^{2}}
$$

where: $\frac{d}{2} \geq a+(i-1) \cdot c$, and $i$ is the number of cut right to the centre. Hence, for the sash gang saw, the average workpiece thickness $H_{\mathrm{P}}$ is a ratio of $H_{\Sigma}$ to the number of saw blades $n_{\mathrm{sb}}$.

Computations of cutting power were carried out in each case for one saw blade, and the obtained values were compared to $P_{\mathrm{cA}}^{1}$ available cutting power per one saw blade (Tab. 1). The latter was calculated as follows:

$$
P_{\mathrm{cA}}^{1}=\frac{\left(P_{\mathrm{EM}}-P_{\mathrm{i}}\right) \cdot \eta_{\mathrm{m}}}{n_{\mathrm{sb}}}
$$

where: $\eta_{\mathrm{m}}$ is mechanical efficiency of the main driving system (for each machine tool $\eta_{\mathrm{m}}=0.85$ was assumed).

\section{RESULTS AND DISCUSSION \\ 4. REZULTATI I RASPRAVA}

Predictions of the cutting model that includes work of separation in addition to plasticity and friction in the case of sawing dry pine wood of the Baltic Natural Forest Region (A) provenance on examined sawing machines are shown in Fig. 7. The reduction in $\Phi_{c}$ (Fig. 7a) and increase in $\gamma$ (Fig. 7b) for all values of rake angle $\gamma_{\mathrm{f}}$ for small depths of cut (e.g. uncut chip thickness) according to Atkins (2003, 2009) are the reason for the increase in cutting pressure. Furthermore, an increase in shear plane angle $\Phi_{\mathrm{c}}$ is observed when rake angle $\gamma_{\mathrm{f}}$ has a larger value.

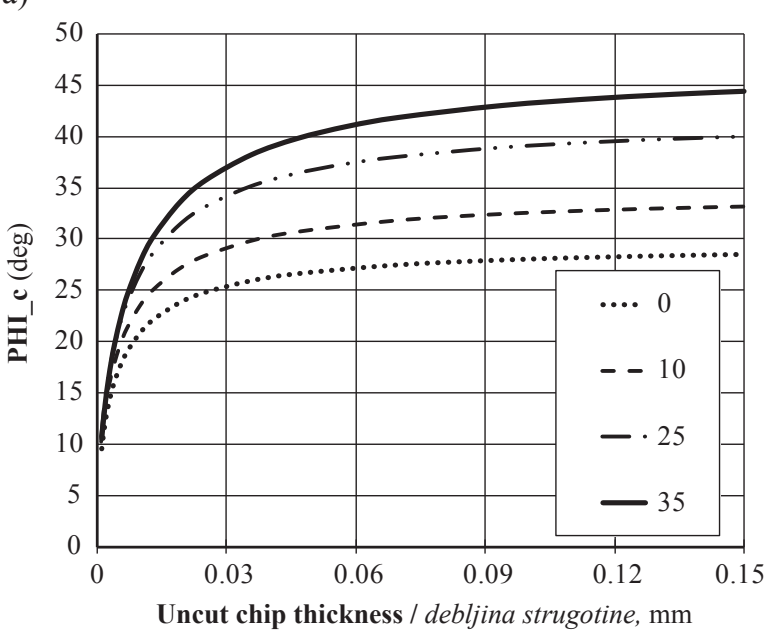

b)

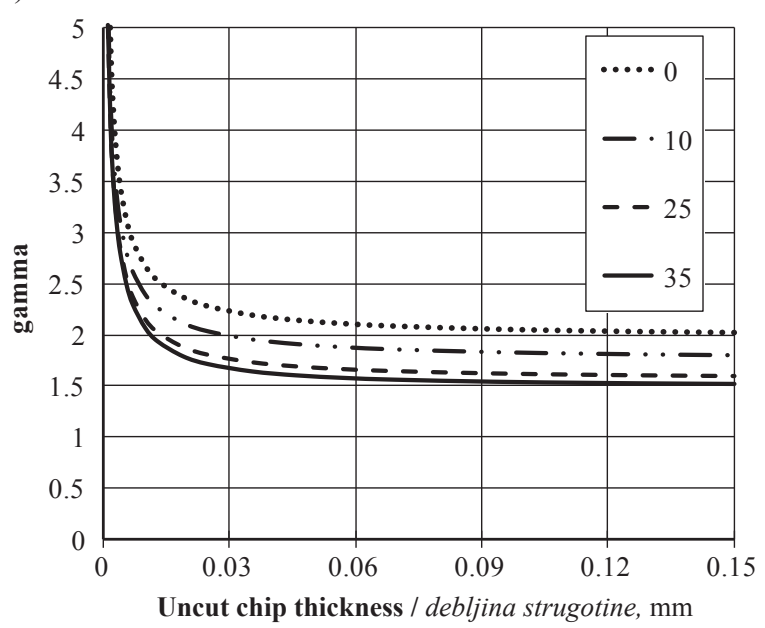

Figure 7 Predictions of cutting model that includes work of separation in addition to plasticity and friction in the case of sawing dry pine wood on examined sawing machines (a) shear plane angle $\Phi_{\mathrm{c}}$ vs. $f_{z}$ (b) primary shear strain $\gamma$ vs. $f_{z}$, in a function of uncut chip thickness $h$ and rake angle $\gamma_{f}$

Slika 7. Predviđanja za model rezanja koji obuhvaća rad odvajanja uz plastičnost i trenje pri piljenju suhe borovine na ispitivanim strojevima: (a) kut ravnine smicanja $\Phi_{c}$ vs. $f_{z^{\prime}}$ (b) primarna čvrstoća smicanja $\gamma$ vs. $f_{z}$, kao funkcija debljine strugotine $h$ i prednjeg kuta $\gamma_{\mathrm{f}}$ 


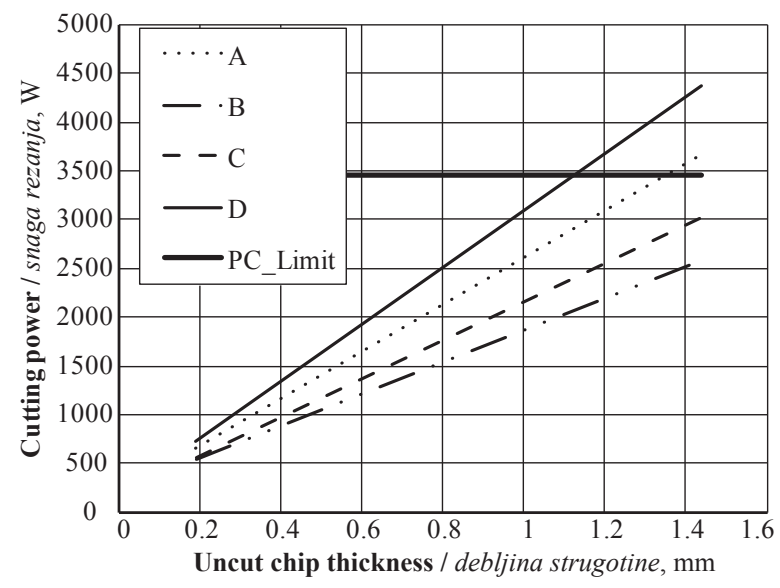

Figure 8 Predicted cutting power for one saw blade for the frame sawing machine DTRB 63

Slika 8. Predviđena snaga rezanja za jedan list pile jarmače DTRB 63

Results of predictions of cutting powers obtained with the use of cutting models that include work of separation in addition to plasticity and friction, and chip acceleration power variation in the case of sawing of pine coming from different Polish regions with one saw blade are shown: in Fig. 8 for the frame sawing machine DTRB 63, in Fig. 9 when using the bandsawing machine ST100R, and in Fig. 10a (upper spindle) and Fig. 10b (lower spindle) for cutting on the rip saw PWR422. For both, the rip saw and the bandsawing machine, the results of the chip acceleration power $P_{a c}$ have been taken into account.

For analysed sawing patterns of the actual Polish sawmill, the capacity of the three sawing machines could be discussed in terms of available power for pine wood of different provenance:

1. For the sash gang saw DTRB 63, it is impossible to apply maximum values of feed speed for every kind of pine wood (it concerns the raw material derived from the Baltic Natural Forest Region (A) and the Great Poland-Pomeranian Natural Forest Region (D)).

a)

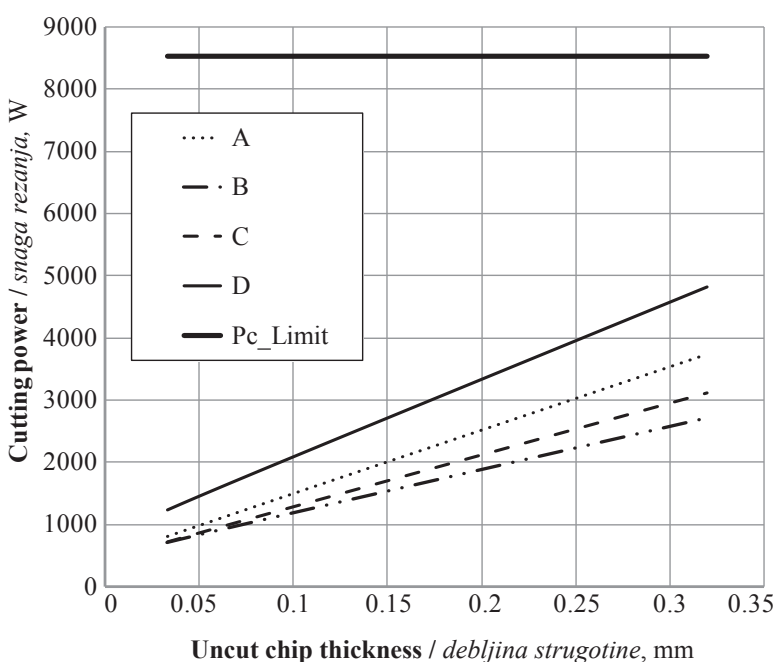

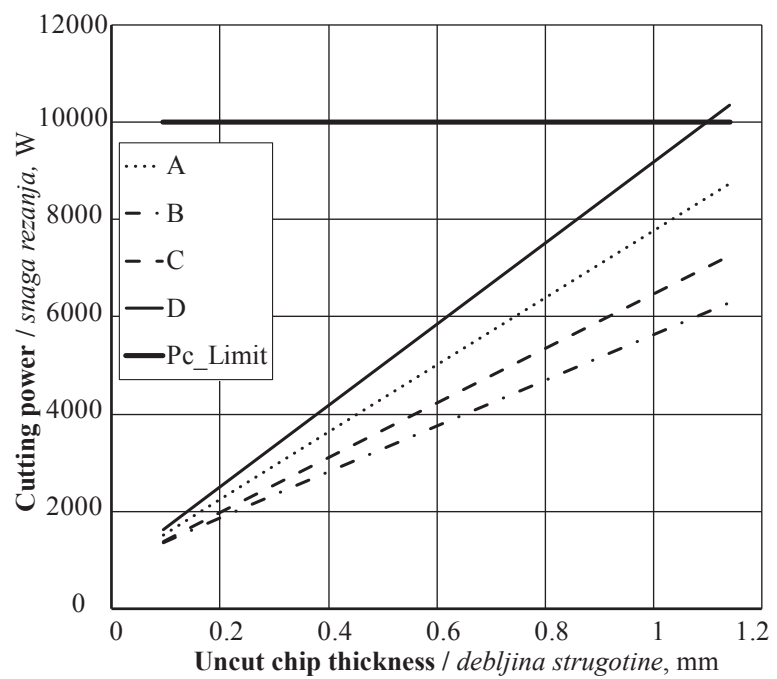

Figure 9 Predicted cutting power for the bandsawing machine ST100R

Slika 9. Predviđena snaga rezanja za tračnu pilu ST100R

2. For bandsaw ST100R sawing pine wood from the Great Poland-Pomeranian Natural Forest Region (D), the cutting power could surpass the accessible cutting power in the cutting zone almost at maximum values of feed speed.

3. For the rip saw PWR422, the accessible cutting power in the cutting zone (per one saw blade) is not exceeded, because the workpiece height (cutting depth) is automatically divided among two spindles as a $2 / 3$ ratio, and simultaneously the maximum value of feed speed is not so high compared to other machine tools currently present on the European market.

It ought to be emphasised that only the obtained cutting powers for pine wood of the Baltic Natural Forest Region (A) provenance (in each case of sawing the second line from the top in plots, Fig. 8-10) correspond to values calculated with empirical models presented e.g. by Manžos (1974) and Orlicz (1988). This piece of evidence could be stated, since, in the paper by Or-

b)

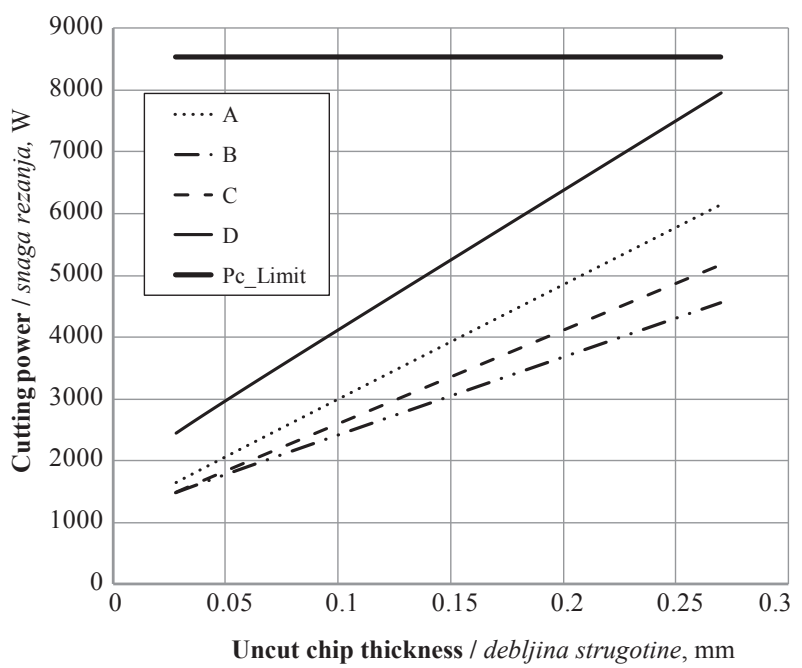

Figure 10 Predicted cutting power for one circular saw blade for the rip saw PWR422, where: a - upper spindle, b - lower spindle

Slika 10. Predviđena snaga rezanja za jedan list kružne pile PWR422: a) za gornje vreteno, b) za donje vreteno 
lowski et al. (2013), it has been proved that the specific cutting resistance is in conformity with values calculated with the use of the mentioned empirical calculation models. Furthermore, the size effect was present for the cutting power prediction method, which is based on the fracture mechanics. For other locations (Regions B, C and D) of the raw material origin examined in this paper, cutting powers significantly differ from the cutting power values of pine wood originated from Region (A) because MOR, fracture toughness and simultaneously shear yield stresses significantly vary (shown in Table 2). Additionally, variability in properties is common to all materials. Since wood is a natural material and the tree is subject to many constantly changing influences (such as moisture, soil conditions, and growing space), wood properties vary considerably, even in clear material (Kretschmann, 2010; Krzosek, 2009). The same could be noticed in dispersion of the raw material data presented in Tab. 2.

Hence, it has been demonstrated that the approach to predictions of cutting powers obtained with the use of cutting models that include work of separation in addition to plasticity and friction, together with the chip acceleration power variation, is simultaneously an universal and useful tool for forecasting of energetic effects of sawing of every kinematics.

\section{CONCLUSIONS}

5. ZAKLJUČAK

The conducted forecasting of energetic effects with the use of cutting models that include work of separation in addition to plasticity and friction, together with the chip acceleration power variation, once more corroborated their versatility and revealed the efficacy for every known type of sawing kinematics (sash gang saw, bandsawing machine and circular sawing machine).

Furthermore, the conducted analyses revealed that the provenance of the raw material really affects an energetic demand of the cutting process.

This kind of approach to the forecasting of energetic effects while wood sawing allows the sawmill management to estimate the capacity of the rip sawing machines in terms of available power for pine wood of different provenance in advance before processing. It could also be an appropriate method for planning of the proper sawing pattern according to the available power of the sawing machine.

\section{Acknowledgements - Zahvala}

The authors would like to thank Dr. Sc. Krzosek S. (Faculty of Wood Technology, Warsaw University of Life Sciences-SGGW, PL) for the donation of the raw material used in the preliminary tests. A part of this paper was presented at the International Scientific Conference FORTECHENVI 2013 held in Brno (CZ) 26-30 May 2013. The financial assistance of the Ministry of Science and Higher Education, Poland, Grant N N 508629840 is also kindly acknowledged. The authors would like to thank the firm PPH GASSTECH
Sp. z o.o. for cutting tools data, and the COMPLEX Sawmill (Poland) for sawing process data.

\section{REFERENCES}

\section{LITERATURA}

1. Atkins, A. G., 2003: Modelling metal cutting using modern ductile fracture mechanics: quantitative explanations for some longstanding problems. International Journal of Mechanical Sciences, 45: 373-396. http://dx.doi.org/10.1016/S0020-7403(03)00040-7.

2. Atkins, A. G., 2009: The science and engineering of cutting. The mechanics and process of separating, scratching and puncturing biomaterials, metals and non-metals. Butterworth-Heinemann is an imprint of Elsevier, Oxford.

3. Aydin, S.; Yardimci, M. Y.; Ramyar, K., 2007: Mechanical properties of four timber species commonly used in Turkey. Turkish J. Eng. Env. Sci., 31 (1): 19-27.

4. Beer, P., 2002: Obróbka skrawaniem obwodowym drewna nowo opracowanymi narzędziami. (In Polish: Wood peeling with new elaborated tools). Roczniki Akademii Rolniczej w Poznaniu, Rozprawy Naukowe, Zeszyt 330. Wydawnictwo Akademii Rolniczej im. Augusta Cieszkowskiego w Poznaniu, Poznan.

5. Csanády, E.; Magoss, E., 2013: Mechanics of Wood Machining. Springer-Verlag Berlin Heidelberg. 199 p http:// dx.doi.org/10.1007/978-3-642-29955-1.

6. FPL (Forest Products Laboratory), 1980: Structure of Wood. Research Note, March. FPL-04, United States Department of Agriculture Forest Service.

7. Glass, S. V.; Zelinka, S. L., 2010: Moisture Relations and Physical Properties of Wood (Chapter 4). In: Wood Handbook - Wood as an Engineering Material (Centennial Edition). General Technical Report FPL-GTR-190. Madison, WI: U.S. Department of Agriculture, Forest Service, Forest Products Laboratory. 508 p. http://www.fpl.fs.fed.us/documnts/fplgtr/fpl_gtr190.pdf

8. Kretschmann, D. E., 2010: Mechanical Properties of Wood (Chapter 5). In: Wood Handbook - Wood as an Engineering Material (Centennial Edition). General Technical Report FPL-GTR-190. Madison, WI: U.S. Department of Agriculture, Forest Service, Forest Products Laboratory. 508 p.

http://www.fpl.fs.fed.us/documnts/fplgtr/fpl_gtr190.pdf

9. Krzysik, F., 1974: Nauka o drewnie. (In Polish: Wood science). PWN, Warszawa.

10. Jeronimidis, G., 1980: The fracture behaviour of wood and the relations between toughness and morphology. Proc. R. S. Lond. B 208, 447-460.

11. Krzosek, S., 2009: Wytrzymałościowe sortowanie polskiej sosnowej tarcicy konstrukcyjnej różnymi metodami. (In Polish: Strength grading of Polish structural sawn timber with different methods.) Wydawnictwo SGGW, Warszawa, $127 \mathrm{p}$.

12. Laternser, R.; Gänser, H. P.; Taenzer, L.; Hartmaier A., 2003: Chip formation in cellular materials. Transactions of the ASME, 125: 44-49.

13. Leśnik, 2013: LasyRej_20130110. Obsługa drewna kłodowanego. Podręcznik użytkownika. System Informatyczny Lasów Państwowych. Lasy Państwowe. Warszawa, styczeń. 21 p.

14. Manžos, F. M., 1974: Derevorežuŝie Stanki. (In Russian: Wood cutting machine tools). Izdatel'stvo "Lesnaâ promyšlennost", Moskva.

15. Naylor, A.; Hackney, P.; Perera, N.; Clahr, E., 2012: A predictive model for the cutting force in wood machining developed using mechanical properties. BioRes. 7(3): 2883-2894. 
16. Orlicz, T., 1988: Obróbka drewna narzędziami tnącymi. (In Polish: Wood machining with cutting tools.) Skrypty SGGW-AR w Warszawie, Wydawnictwo SGGW-AR, Warszawa.

17. Orlowski, K., 2007: Experimental studies on specific cutting resistance while cutting with narrow-kerf saws. Advances in Manufacturing Science and Technology, 31(1): 49-63.

18. Orlowski, K. A., 2010: The fundamentals of narrow-kerf sawing: the mechanics and quality of cutting. Technical University in Zvolen, Publishing house of the Technical University in Zvolen.

19. Orlowski, K. A.; Atkins, A., 2007: Determination of the cutting power of the sawing process using both preliminary sawing data and modern fracture mechanics. pp. 171-174. In: Navi, P., Guidoum, A. (eds.). Proc. of the Third Inter. Symposium on Wood Machining. Fracture Mechanics and Micromechanics of Wood and Wood Composites with regard to Wood Machining, 21-23 May, Lausanne, Switzerland. Presses Polytechniques et Universitaires Romandes, Lausanne.

20. Orlowski, K. A.; Pałubicki, B., 2009: Recent progress in research on the cutting process of wood. A review COST Action E35 2004-2008: Wood machining - micromechanics and fracture. Holzforschung, 63: 181-185 http://dx.doi.org/10.1515/HF.2009.015.

21. Orlowski, K. A.; Ochrymiuk, T.; Atkins, A., 2010: Specific cutting resistance while sawing of wood - the size effect. Ann. WULS-SGGW, Forestry and Wood Technology, 72: 103-107.

22. Orlowski, K. A.; Ochrymiuk, T.; Chuchala, D., 2012: Prognozowanie mocy skrawania przy przecinaniu polskiego drewna sosnowego na pilarkach tarczowych. Artykuł na płycie CD dołączonej do czasopisma. (In Polish, Forecasting of cutting power while sawing Polish pine wood on circular sawing machines. The paper enclosed to the journal on CD.) Mechanik, (8-9): 661-663.
23. Orlowski, K. A.; Ochrymiuk, T.; Atkins, A.; Chuchala, D., 2013: Application of fracture mechanics for energetic effects predictions while wood sawing. Wood Sci Technol, Volume 47, Issue 5, pp. 949-963., DOI 10.1007/s00226-013-0551-x. (Open access).

24. Pantea, R. C., 1999: Wood cutting system: modelling and process simulation. Mémoire présen té à la Faculté des études supérieures de l'université Laval pour l'obtention du grade de maître ès science (M. Sc.). Département de génie mécanique FACULTÉ DES SCIENCES ET DE GENIE, UNIVERSITÉ LAVAL (National Library of Canada).

25. Scholz, F.; Duss, R.; Hasslinger, R.; Ratnasingam, J., 2009: Integrated model for the prediction of cutting forces. pp. 183-190. In: Handong Zhou, Nanfeng Zhu, Tao Ding (eds.). Proc. of $19^{\text {th }}$ International Wood Machining Seminar., October 21-23, Nanjing, China, Nanjing Forestry University.

26. Stenner, 2011: ST100R Radial Arm Resaw, Stenner Ltd. (pdf, leaflet).

27. Web_Source 1, 2013:

http://www.tos.cz/indexan.php?stranka=rozpily3 (access, March 2013).

\section{Corresponding address:}

Professor KAZIMIERZ A. ORLOWSKI, Ph. D.

Gdansk University of Technology

Faculty of Mechanical Engineering

Department of Manufacturing Engineering and

Automation

Narutowicza 11/12

80-233 Gdansk, POLAND

e-mail: korlowsk@pg.gda.pl 